\title{
OTTOMAN OFFICIAL ATTITUDES TOWARDS AMERICAN MISSIONARIES*
}

\author{
ÇAĞRI ERHAN
}

\begin{abstract}
Members of various American missionary organizations, mainly affiliates of American Board of Commissioners for Foreign Missions (ABCFM, the Board) started to visit the Levant region in the second decade of the nineteenth century. Moving out from Beirut, the missionaries established protestant churches, schools, hospitals and other social facilities mostly in non-Muslim populated areas of the Empire. While during early years of Ottoman-American encounters the Sublime Porte was indifferent towards missionary activities among its subjects, the official attitude gradually changed and became negative in the following years, paralleling the increase in the number of complaints from non-Muslim clergy, the Muslims and the government officials. While the missionary activities gave impetus to the awakening of nationalism among some of the non-Muslim subjects of the Empire, such as Armenians and Bulgarians, Ottoman negative approach to American missionaries reached its climax during the last quarter of the nineteenth century. Accordingly, this article evaluates the causes and process of the change in the Ottoman official attitude towards the American missionaries.
\end{abstract}

\section{KEYWORDS}

Turkey and the United States; Ottoman Empire; American Missionaries; American Philanthropy; United States and the Middle East.

\footnotetext{
${ }^{*}$ This is a revised and enlarged version of a paper delivered to International Conference on "The United States and the Middle East: Cultural Encounters", Yale University, 7-8 December 2000.
} 


\section{Introduction}

The history of Turkish-American relations has a long past dating back to 1790s when American sailors met with Turks in the North Africa (Barbary Coast). During the period between 1800 and 1830s American travelers and merchants frequently visited Turkish harbors, such as İzmir (Smyrna), Alexandria and Beirut. The official diplomatic relations were inaugurated in 1830 when the Treaty of Commerce and Navigation was signed in İstanbul and a charge d'affaires, David Porter was appointed as the American representative to the Sublime Porte (the Ottoman Court) in 1831.1

Along with the commercial relations, American missionary efforts in the Ottoman lands always occupied a high place in the bilateral agenda. In fact, most of the diplomatic conflicts in the nineteenth and early twentieth century Turkish-American relations originated from the American missionaries' gradually expanding activities in the Ottoman lands.

This paper, after a brief information on the expansion of the missionary activities in the Ottoman Empire, will examine the main points of dispute between the Sublime Porte and the missionaries under three titles, namely "Missionaries and Ottoman Subjects"; " Missionary Schools and other Facilities" and "Publishing Activities of the Missionaries". Finally it will evaluate the affects of the existence of American missionaries throughout the Ottoman lands.

When American Board of Commissioners for Foreign Missions (ABCFM, the Board) was formed in Boston by members of the Congregational, Presbyterian and Reformed churches in 1810, its main target was to evangelize the Indians and Catholics in American continent. However, shortly after its establishment, the Board identified a new target, "evangelization of the whole World", and started to enlarge the scope of its activities. ${ }^{2}$ In accordance with the decision taken in a meeting of the Board in 1818, two

\footnotetext{
1John P. Brown, "An Audience with Sultan Abdul Mejid", The Knickerbocker, Vol. XIX, June 1842, p. 497.

${ }^{2}$ A. C. A Schneider, Letters from Broosa Asia Minor, Pennsylvania, 1846, p. 39.
} 
American missionaries Pliny Fisk and Levi Parsons were appointed to implement preparatory work in the Ottoman Empire. ${ }^{3}$

The first attempts at missionary work in the Ottoman lands were not directed particularly toward the Muslims, nor to the Oriental Churches, but to the Jews, as in November 1819, Fisk and Parsons were sent out to work in Palestine, with their anticipated headquarters at Jerusalem. But their instructions gave them ample range. From the heights of Zion they were to survey, not only the Holy Land, but surrounding countries, and then put to themselves two main questions: "What good can be done?" and "By what means?": "What can be done for Mohammedans? What for Christians? What for the people in Palestine? What for those in Egypt, in Syria, in Persia, in Armenia, in other countries to which your inquiries may be extended?". 4

Soon after they reached the Ottoman land, Parsons died in 1821. But Fisk continued his mission. He visited Beirut, Tripoli, Baalbek, Jaffa, Jerusalem, Hebron, Alexandretta and Latakia, collecting information on Turks, Arabs, Kurds, Druzes, Maronites, Greeks and Armenians. He was able to convert some Armenians including two ecclesiastics, Gregory Wortabet and Garabed Dionysius. ${ }^{5}$ Fisk also established a missionary printing house in Malta in 1822 to publish religious books in regional languages such as Greek, Armenian and Arabic. ${ }^{6}$

As the first contacts with the missionaries were welcomed by the Armenian people, the Prudential Committee of the Board decided to establish a mission among Armenians in the Ottoman Empire in 1829. Accordingly, Eli Smith and Henry Otis Dwight were chosen to explore the field. They started their tour in the spring of 1830 , and after more than a year, returned with a mass of new information, both in regard to Armenians and Nestorians. In

${ }^{3}$ Uygur Kocabaşoğlu, Kendi Belgeleriyle Anadolu'daki Amerika, Istanbul, Arba, 1989, p. 22.

${ }^{4}$ William E. Strong, The Story of the American Board, Boston, The Pilgrim Press, 1910, p. 80.

${ }^{5}$ H. G. Dwight, Christianity Revived in the East, New York, Baker \& Scribner, 1850, pp. 10-11; Strong, The Story, p. 84.

${ }^{6}$ Kocabaşoğlu, Kendi Belgeleriyle Anadolu'daki Amerika, p. 33. 
1831 William Goodell was instructed to proceed to İstanbul to establish a new station there with special reference to Armenians. ${ }^{7}$

Missionary work, started in 1820 s in a modest manner, turned into a systematic and large scale activity in 1840 s and reached its climax during the last quarter of the nineteenth century. The number of missionaries sent to the Ottoman Empire reached 41 until 1836, and between 1836-1844, 54 new missionaries were appointed to the posts in the Levant. ${ }^{8}$ Finally, the number reached 137 in 1875,177 in 1890 and 209 in $1913.9^{9}$

Missionary influx to the Ottoman Empire was in parallel with the growth of their religious and educational activities. While there were only seven churches and seven schools in 1850 under the control of American missionaries in the Empire, the number went up to 49 churches and 114 schools in 1860, 97 churches and 331 schools in 1880, and 163 churches and 450 schools in 1913. The number of the Ottoman subjects attending those schools was 13.095 in 1880 and 25.992 in $1913 .{ }^{10}$

At the beginning, the relations between the Sublime Porte and the missionaries were conducted without any problems. While there was no diplomatic treaty and relations between the Ottoman Empire and the United States up until 1830 and the United States was not officially recognized by the Porte, American citizens, including the missionaries, conducted their activities in the Ottoman lands under patronage of the British Embassy in İstanbul and through British consulates located in various cities of the Empire. For instance the missionaries in Beirut gained travel permits (seyahat tezkeresi) from the Porte through the British

${ }^{7}$ Dwight, Christianity Revived, pp. 19-21.

${ }^{8}$ H. G. Dwight, Constantinople, Settings and Traits, New York, Harper \& Brother, 1916, p. 227.

${ }^{9}$ Robert Daniel, American Philantrophy in the Near East, 1820-1960, Athens, Ohio University Press, 1970, p. 94.

10Joseph L. Grabill, Protestant Diplomacy and the Near East: Missionary Influence on American Policy 1810-1927, Minneapolis, University of Minnesota Press, 1971, p. 17; Daniel, American Philantrophy, p. 94. 
Consulate in that town. This method was valid for all those who came to İstanbul before an American Legation was opened. ${ }^{11}$

Since, as early as 1813 , the British Bible Society became interested in the spiritual condition of the non-Muslim Ottoman subjects and their members paid visits to the Empire to distribute thousands of copies of the Bible, the Sublime Porte did not make any distinction between the British clericals and the American missionaries and evaluated the members of English speaking Protestant churches under the same identity, i.e. "British". On the other hand, as the British Embassy and consulates had a growing influence on the Ottoman central government and local authorities, British missionaries did not face any difficulties while traveling in the Empire. Thus Americans benefited the same privilege as they were bearing documents of protégé signed by British officials. Finally, during 1820-1830, the missionary activities were limited with certain areas far from the capital such as Palestine and Lebanon and did not take much attention of the Sublime Porte.

When a treaty finally signed between the Ottoman Empire and the United States in 1830, the missionaries as well as other American citizens lost their privilege of being "British" subjects before the Ottoman Court. Since the American legation in İstanbul was not as influential as the British one and the American consulates were not spread around the Empire, the American missionaries continued to seek close relations with the British diplomats in order to secure their presence in the Ottoman lands. Parallel to the increase in the missionary activities in 1830s and 1840 s, more and more problems arose and the official attitude of the Sublime Porte towards the missionaries became less elastic in succeeding years.

The problems of this period may be classified under three main groups. First, the missionary activities among non-Muslim subjects of the Empire caused an initial reaction from the clergy of the Oriental churches, then the issue became a concern of the Sublime Porte. Second, opening of missionary schools sometimes caused difficulties. And, third, the scope of missionary publishing

${ }^{11}$ William Goodell, Forty Years in the Turkish Empire, New York, Robert Carter \& Brothers, 1883, p. 99. 
activities contradictory to the Ottoman law became a major field of permanent friction.

\section{Missionaries and the Ottoman Subjects}

The Christian population of the Empire was not the primary objective of the American missionaries. But since the Jews as a religiously well organized community were isolated from foreign intervention and the Muslims were kept away from religious conversion by heavy regulations including the death penalty for those who convert to any other religion, the missionaries soon changed their areas of activity and mostly intensified on the nonProtestant Christian subjects of the Ottoman Empire. This new domain included the Greek and Arab Orthodox community, the Gregorian Armenians and Armenian Catholics, the Druze, the Nestorians and the Maronites who were Arab Catholics.

When the Syrian mission was established in Beirut in the first half of 1820 s, its main objective was to conduct religious and educational activities among Christians other than Protestants. The work expanded speedily. In 1827 , there were 13 missionary schools in and around Beirut with 600 pupils. The first opposition against the missionaries came during those early years. Started among the Roman Catholics rather than among the Turks or Armenians, it was particularly directed against the missionary schools and printing press. To the influence of Rome, working through its priests, was added that of French and Russian officials, scheming to crush out missionary efforts. With such ecclesiastical interference and the political disturbance of the Greek insurrection in 1826 , the situation appeared alarming to the missionaries. In the general lawlessness, houses of some missionaries were plundered, and the Maronite Bishop (Patriarch), coming down from his monastery in the Mount Lebanon (Cebel-i Lubnan), asked his people to drive out the missionaries, threatening at the same time to excommunicate anyone who should rent a house to them. ${ }^{12}$

After a peaceful period of 15 years, in 1841 another serious reaction of Maronites occurred in Cebel-i Lubnan. The Maronite Bishop, who had earlier applied to the governor of Syria, Zekeriya

${ }^{12}$ Strong, The Story, p. 83-84. 
Pasha, to complain about the "destructive" works of missionaries among the local population, asked the Ottoman authorities to suspend their activities. When the governor communicated the situation in Lebanon to capital as alarming, the Sublime Porte delivered a note verbal to David Porter, then the United States minister resident in İstanbul, in May 1841 and asked him to urge the missionaries to leave Lebanon. The Porte also emphasized its concern about the lives of the missionaries should the tension increase. However Porter, in his reply to the Porte, stated that the American legation could neither force the missionaries to withdraw from the region, nor bear their responsibility. ${ }^{13}$

Thus the missionaries continued their presence in Mount Lebanon. According to Chapseaud, the United States consul in Beirut, the tension in the region was not caused by the missionaries, and the missionary schools were built outside the Maronite area. ${ }^{14}$ The facts were different. There was a historical feud between the Maronites and the Druzes, who both had a large number of kins living in the Cebel-i Lubnan. American missionaries, while building schools in the area dominated by the Druze, were using the intercommunal conflict to protect themselves from Maronite intervention. But the "Druze Shield" failed to protect them, when clashes between the Maronites and the Druze increased in Fall 1841. Along with many Druze buildings, some American mission stations and schools were also destroyed by the Maronites. The Sublime Porte's warning this time was critical and the missionaries withdrew from the Cebel-i Lubnan to Beirut. ${ }^{15}$ They did not initiate any efforts in the region for a couple of years.

From 1844 onwards, the Armenian clergy also began to complain about the missionaries to the Sublime Porte. Matteos, the Armenian Patriarch of İstanbul, whom the Ottoman government recognized as the only representative of the Armenian millet (nation), accused the missionaries of forcing the Armenians to change their religion. During the early years of American missionary activities among the Armenians, the general atmosphere

${ }^{13}$ National Archives and Records Administration, Maryland, USA ("NARA" hereafter), M-46 (Despatches from US Ministers to Turkey to the Deparment, 1818-1906), May 16, 1841.

${ }^{14}$ NARA, M-46, August 1, 1841.

${ }^{15}$ NARA, M-46, October 1, 1841. 
was friendly. Armenians, benefited from American educational activities in a positive way, welcomed the missionaries. But, as the number of Armenian converts to Protestantism increased, the Armenian clergy changed its attitude. In 1839, only in İstanbul, there were 800 converts, a disturbing number for the Armenian Patriarchate. ${ }^{16}$ In order to prevent more Armenians to change their religion, Matteos called all Armenians to cut any sort of relations with the American missionaries and threatened those who were in "warm" contacts with the Americans, by isolation from the community. ${ }^{17}$

Moves of the Armenian patriarchate were supported by the Sublime Porte that did not recognize a Protestant millet, thus interpreted the existence of Protestant Armenian subjects as illegal. One should also keep in mind that many Armenian Gregorians occupied high places in the Ottoman bureaucracy, and they were in touch with the Patriarchate in opposition to the missionaries. When more complaints from the Armenians reached to the Porte, Ottoman government once more confronted the United States legation in İstanbul. In June 1844, Armenians from Erzurum, Trabzon (Trebizond) and Bursa (Broosa) applied to the Porte and wanted the American missionaries to be expelled from their towns. The basic reason of the complaint was conversion. Rifat Pasha, the Minister of Foreign Affairs, sent a note to the United States Legation and call for missionaries' withdrawal. But, as in the Lebanon case, John P. Brown, the American charge, stated that he could not urge the missionaries to leave the towns. But, this time the Porte was more determinant and by orders to the local authorities in those three towns, missionaries' conversion efforts were banned and Protestantism among Armenians once more proclaimed illegal. ${ }^{18}$

Another complaint from Armenians to the Porte came in 1845, when an Armenian woman in Beirut accused the American missionaries for kidnaping her three children and forcing them to

${ }^{16}$ Goodell, Forty Years, p. 132.

${ }^{17}$ Strong, The Story, p. 105; Grabill, Protestant Diplomacy, p. 13; Dwight, Constantinople and Settings, p. 269.

${ }^{18}$ Bassbakanlık Osmanlı Arssivi (Prime Ministery, Ottoman Archives), İstanbul, Turkey ("BOA" hereafter), C.H. (Cevdet Hariciye), 2 C. 1260, June 19, 1844; 8 C. 1260, June 25, 1844. 
change their religion. When the Ottoman governor in Damascus applied to the United States Consul in Beirut for release of the children, he was replied that without an official instruction from the Legation in İstanbul, the Consul could not interfere in the affair. The Sublime Porte then sent a definite note to the American Legation and asked their cooperation. As the American Consul, instructed from İstanbul, took the issue in hand, the children were given back to their parents. ${ }^{19}$

Between the years 1844 and 1845 , the number of notes from the Sublime Porte to the United States Legation was increased. Dabney S. Carr, who were appointed as the American minister resident to İstanbul in 1843, dispatched to the Department of State in 1844 and 1845, that the Sublime Porte was not disturbed by the humanitarian dimension of the missionary activities but, due to the pressures from Christian clergy, the issue became a major point of conflict. Carr summarized the basic objection of the Porte in three titles. According to Carr, first, the Ottoman government was against conversion among its Christian subjects and found this practice as illegal. Second, the Porte was in fear that if the number of converts would increase, it would cause a chaos in administration. And third, the increase in the number of protégé documents released to the Protestants in the Ottoman Empire by the United States consuls caused a deep concern in the Porte. ${ }^{20}$

Armenian Patriarch Matteos expelled the Protestant Armenians from the Armenian Gregorian Church in 1846. He also wrote a comprehensive letter of complaint to the Sublime Porte. Therefore the Porte once more applied to the United States Legation and wanted the American minister to stop the activities of missionaries among the Armenians. This call, as previous ones, had no affirmative answer neither from the Legation, nor from the missionaries. $^{21}$

The Matteos' move against Protestant Armenians created an administrative problem. The Sublime Porte classified the Ottoman subjects according to their religion. There were Muslim, GreekOrthodox, Armenian, Jewish and Catholic millets in the Ottoman

${ }^{19}$ BOA, C.H., 24 M. 1261, February 2, 1845.

20NARA, M-46, December 9, 1844; March 27, 1845.

${ }^{21}$ NARA, M-46, March 1, 1846. 
population. Since there was not a Protestant nation recognized by the Porte, those who converted to Protestantism were losing their official identity before the Sublime Porte. Thus, there was no an authority representing them. As the number of converts increased, the problem of identity and representation became more critical, and in order to obtain a status of nation, the American missionaries during the 1840s ran an intensive camping through the British Embassy and the United States Legation over the Sublime Porte.

The United Kingdom, who proclaimed herself as the protector of the Protestants in the Ottoman Empire, in seeking the recognition of a Protestant nation status, gave support to American missionaries. British Ambassadors in İstanbul, Stratford Canning (in future Viscount Stratford de Redcliffe) and Lord Cowley, in their contacts with Mustafa Reşid Pasha, the Grand Vizier, mostly emphasized the British Empire's will of the creation of Protestant nation. After a period of heavy diplomatic pressures on the Porte, Sultan Abdülmecid issued a imperial order (irade) on 15 November 1847 and granted the status. Following the decree, the Protestants of the Ottoman Empire chose a representative (vekil) who would in future conduct their relationship with the Sublime Porte. ${ }^{22}$ Some important points of the order were as follows:

To His Excellency, the Pasha Controller of the City Revenue,

Whereas the Christian subjects of the Ottoman Government professing Protestantism have experienced difficulty and embarrassment from not being hitherto under a special and separate jurisdiction, and naturally the Patriarch and the heads of the sects from which they have separated not being able to superintend their affairs, and whereas it is in contravention to the supreme will of his Imperial Majesty our Gracious Lord and Benefactor (may Allah increase him in years and power) animated as he is with feelings of deep interest and clemency towards all classes of his subjects, that any of them should be subjected to grievance, and whereas the aforesaid Protestants, in conformity with the creed professed by them, do form a separate community, it is His Imperial Majesty's supreme will and command that for the sole purpose of facilitating their affairs, and of securing the welfare of said Protestants, the administration thereof should be

${ }^{22}$ Dwight, Christianity Revived, pp. 252-285; William Goodell, The Old and the New or Changes of Thirty Years in the East, New York, 1854, p. 83. 
henceforward confided to Your Excellency, together with the allotment of the taxes to which they are subjected by law, that you do keep a separate register of their births and deaths in the bureau of your department, according to the system observed with regard to Latin subjects, that you do issue passports and permits of marriage, and that any person of established character and good conduct chosen by them to appear as their agent at the Porte for the transaction and settlement of their current affairs, be duly appointed for that purpose.... 23

After the proclamation of the order, American missionaries in İstanbul sent a letter to the British ambassador, and offered their "sincere congratulations on the successful termination of [his] efforts in behalf of the Protestant subjects of the Porte." The missionaries depicted their gratitude in the following sentences:

Through the humane interposition of his excellency, Sir Stratford Canning, the Protestant subjects of Turkey found substantial relief from the persecutions under which they were then suffering; and since, by the untiring efforts of your Lordship, the very important point has been conceded for them, that in regard to liberty of conscience and the enjoyment of civil rights, they shall be placed on the same footing with all other Christian subjects of the Porte. ${ }^{24}$

Although the Protestant irade maintained a relief and more proper climate for the Protestant subjects of the Porte, it did not curtail the American misisonary works in the Ottoman Empire. Missionary efforts continued to be an area of complaint for the Ottoman Government.

\section{Problems Arising from the Missionary Schools and Other Facilities}

Missionary spread in the Ottoman Empire was through two ways: mission stations and missionary schools. After establishment of a mission in İstanbul as a center for all missionary activities in the Ottoman Empire, more stations were opened in Asian and European Turkey. Stations in Trabzon (1835), Erzurum (1839), Aintab (1849), Marash (1855), Adana, Aleppo, Tarsus, Hadjin,

\footnotetext{
${ }^{23}$ Dwight, Christianity Revived, pp. 285-286.

${ }^{24}$ Ibid., p. 287.
} 
Alexandretta, Kilis, Salonica (1850) and İzmir (1859) were established. ${ }^{25}$

Alongside the missionary churches and stations, missionary schools established widely in various parts of the Empire. This extensive educational activity caused problems mainly stemming from two different levels. First problem was the reaction of local population and local authorities against the missionary establishment. Second and more important problem was the attitude of the Sublime Porte, which was basically formed through the local reactions.

All missionaries after 1840, who applied the Sublime Porte to obtain travel permits, were warned not to build schools in the mountainous areas. The Sublime Porte, as explained in a note to the United States Legation, was trying to prevent the missionaries from any kind of local assaults, because of their educational efforts. Therefore the Sublime Porte repeatedly stated that it had no responsibility of the well-being of Americans who without an imperial permit committed to build schools. ${ }^{26}$ Parallel to building of more missionary schools, the notes of complaint from the Sublime Porte to the Legation increased. The American minister resident Carr, in one of his dispatches to the State Department in 1848, stressed the change in the attitude of the Sublime Porte towards Americans in a negative way and confessed that the missionaries, who behaved solely independent from any authority, either Ottoman or American, would cause more complaints in future. ${ }^{27}$

The missionary schools were a permanent matter of dispute throughout the nineteenth century, as besides their numbers, their size enlarged too. Beginning in 1860s, the American missionaries initiated to build high schools or colleges, in certain population centers of the Ottoman land. With opening of the colleges, more Ottoman students, mostly non-Muslim, attended these facilities, and more estates owned by Ottoman subjects went under the control of

25James Barton, Daybreak in Turkey, Boston, The Pilgrim Press, 1908, p. 138.

26NARA, M-46, August 7, 1843.

${ }^{27}$ NARA, M-46, August 2, 1848. 
American missionaries. These two factors incited the Porte to move against the missionaries.

First college initiated by the American was opened in Beirut in 1866 under the name of Syria Protestant College (It became Beirut American University in the twentieth century). The language of the courses was Arabic and the people in the region got a chance to take education in medicine and pharmacy as well as social sciences. ${ }^{28}$ Leaving aside minor local objections, the Beirut College did not attract any reaction from the capital. However, when Cyrus Hamlin, a senior missionary, who maintained a generous financial contribution from an American businessman, Christopher R. Robert, intensified his efforts to built an American college out of a small seminary in Bebek, İstanbul, the Sublime Porte refused to give required permits to open a college and to construct buildings.

Although not stated officially in any correspondence between the Porte and the American Legation, one of the reasons of this attitude was the Sublime Porte's discontent with the opening of such a comprehensive foreign educational institution in its capital. This step, as an example, would be followed by the European powers such as France and Russia, and establishment of foreign colleges for the attendance of the non-Muslim pupils would create a new area of conflict between the Ottoman Government and the "Great Powers". Secondly, the Sublime Porte had a great concern about the "negative" effects of the curricula of such institutions on its non-Muslim subjects. Some of the Western values such as liberalism and nationalism, which could have "destructive" reflections on a multi-national empire, should be kept away from the Ottoman subjects. If the role of graduates from American colleges in the rise of Bulgarian, Armenian and Albanian nationalism in the last quarter of the nineteenth century is taken into consideration, one might understand the sensitivity of the Sublime Porte.

Nevertheless, contacts of the American minister in İstanbul, Edward Joy Morris who was instructed by the Department of State, with the Sublime Porte gave an affirmative result for the missionaries, and the objection to establish an American College in

${ }^{28}$ Grabill, Protestant Diplomacy, p. 24. 
İstanbul was withdrawn. But, the Ottoman objection for the place of the school continued to be a point of dispute. The Sublime Porte, namely Ali Pasha, the Minister of Foreign Affairs, was against to the construction of a college building at Rumelihisar, the land which was bought by the missionaries solely for that purpose. Rumelihisarı was then a quarter largely occupied by Muslims and such an institution was likely to cause more problems. In İstanbul, certain quarters, such as Pera, Fener and St. Stephanos were the places where non-Muslims lived and the Sublime Porte wanted to limit the churches, mission stations and missionary schools within those areas. ${ }^{29}$

Soon the building place of the İstanbul College became a subject of the bilateral diplomatic negotiations. The United States Secretary of State William Seward gave a note to the Ottoman minister resident in Washington, Blacque Bey, in the summer of 1868 and asked him to persuade the Sublime Porte to allocate the afore mentioned estate in Rumelihisan for college building. ${ }^{30}$

If it is remembered that the major donor for the College was an notable American businessman, it is easier to understand the basic motive behind Seward's intervention to the case. Just after this note to Blacque Bey, the Department of Navy instructed Admiral Farragut, commander of the United States Mediterranean Squadron, to move to İstanbul on the deck of an American frigate and to "show his utmost effort" in the favor of a construction permit. Farragut's mission in İstanbul in August 1868, resulted with an happy ending for the American missionaries. The Sublime Porte could not resist before an admiral's insist and allowed the missionaries to build the school, which would be named Robert College for Christopher Robert's contribution. ${ }^{31}$

Establishment of Robert College gave an impetus to other initiatives. During the period between 1871-1903, seven more American Colleges were established throughout the Ottoman lands:

${ }^{29}$ Howard Joseph Kerner, Turco-American Diplomatic Relations, 18601880 , unpublished Ph.D Thesis, Washington D.C., Georgetown University, 1948, pp. 160-171.

30NARA, M-99/96 (Notes to the Turkish Legation in the United States from the Department), July 1, 1868.

${ }^{31}$ Kerner, Turco-American Diplomatic Relations, p. 181. 
American Girls' College in İstanbul, Euphrates College in Harput (Kharput), American College in Van, Central Turkey College in Maraş, St. Paul College in Tarsus, Anatolian College in Merzifon (Marsovan) and International College in İzmir (Smyrna). ${ }^{32}$

Establishment processes of all the American colleges caused some minor problems with the local authorities, but those difficulties were solved by peaceful means. However, in 1880's and 1890 s, two major problems, Sultan Abdülhamid's centralized educational reforms and American connection with the Armenian nationalism emerged and became the top priority matter for the Ottoman-American relations.

Sultan Abdülhamid, ascended to the Ottoman throne in 1875 , centralized the whole power in his hands and the Sublime Porte, which was the main center of government for almost 50 years, lost its privileges to conduct internal and diplomatic affairs alone. Abdülhamid, who found a correlation between the foreign intervention of the "Great Powers" and the increasing number of national insurrections of non-Muslim Ottoman subjects, decided to cut their means of external support. Along with some other measures, he banned the transfer of property or the granting of a building permit for a new missionary school. For the schools already built, he utilized new school law that established standards for teacher certification, the curriculum, and the physical facilities of the school. In some cases, the latter measure caused examination of the teaching certificates of all teachers of American schools, and sometimes the schools were closed because the teachers could no longer produce their credentials. ${ }^{33}$

The American missionaries, claiming the right to unrestricted operation of three categories of schools (those owned and taught by American citizens, those owned and directed by Americans but taught by the Ottoman subjects, and those owned and taught by the Ottoman subjects with a subsidy and some supervision from Americans) entered an uneasy struggle with Ylldlz (Abdülhamid's Palace in which he ruled the Empire). The American legation vigorously defended the missionary claims on the first category, while it held that schools in the third group, the majority of the

${ }^{32}$ Grabill, Protestant Diplomacy, p. 26.

${ }^{33}$ Daniel, American Philantrophy, p. 114. 
American schools in the Empire, had no recognizable rights which could be protected by the United States government. The status of the second group of schools remained obscure. In addition, the American legation in its correspondence with the Ottoman Ministry of Foreign Affairs, repeatedly stressed that the newly organized schools should submit their programs of study, their textbook lists, and the diplomas or certificates of their teachers to the examination of the Turkish authorities, but objected for the same measures for existing schools. ${ }^{34}$

When Armenian nationalists started a large scale insurrection in major towns of central and eastern Anatolia in 1890, the Gttoman attitude towards the missionary schools sharpened. Because most of the American schools in problematic areas had Armenian students and Armenian teachers who were in contact with the rebels. The crisis came in 1893-1895 period when American colleges and houses of some American missionaries in Merzifon, Harput and Maraş were damaged during the Ottoman army's intervention to Armenian upheavals. Besides, some of the Armenian teachers of those schools were arrested under the accusation of helping the rebels. ${ }^{35}$ For the destruction of Anatolian College in Merzifon in 1893, the Ottoman government paid 500 Turkish pounds to the United States Legation in İstanbul, granted a permit for rebuilding of damaged parts, and released two Armenian teachers after the reports of confirmation prepared by Jewett, the American Consul in Sivas, and Newsberry, secretary of the American Legation. ${ }^{36}$

However, for the claims of destruction of Euphrates College in Harput and Central Turkey College in Maraş in 1895, the process did not follow the same road. American missionaries, through the American Legation, wanted the Ottoman Government to pay an indemnity of 100.000 dollars for the damages in those two colleges. ${ }^{37}$ But the Ottoman Government did not accept the responsibility of the damage and refused to pay an indemnity. ${ }^{38}$

${ }^{34}$ Kerner, Turco-American Diplomatic Relations, p. 115.

${ }^{35}$ NARA, M-46, February 5, 1893; Frederick Davis Greene, The Rule of the Turk, New York, G. P. Putnam's Sons, 1896, pp. 35-39.

36NARA, April 27, 1893; July 5, 1893.

${ }^{37}$ NARA, M-46, November 27, 1895.

${ }^{38}$ NARA, M-46, December 4, 1895. 
On 4 December 1895, the United States Senate resolved that the President would communicate all kinds of information about the damages to American citizens' property in the Ottoman Empire to the Senate. ${ }^{39}$ Following this resolution, President Cleveland gave a long report to the Senate in which he affirmed that no American citizen had been injured during the incidents, but a damage around 100.000 dollars had been incurred. President also informed the Senate that he had instructed three battleships, (San Fransisco, Marblehead and Minneapolis) to visit Ottoman ports in order to prevent any assaults to the American citizens and to secure an indemnity for the losses. ${ }^{40}$ After the Presidential report, the Senate in January 27, 1896, passed a resolution, drafted by Senator Shelby M. Cullom, Chairman of the Committee of Foreign Affairs, which called on the President to initiate necessary steps to obtain indemnity from the Ottoman Government. ${ }^{41}$

The problem of indemnity remained unsolved until 1901, when an American cruiser, Kentucky was sent to İzmir harbor with orders to sustain pressure on the Ottoman Government until the payment was made. This military threat worked in United States' favor and the Ottoman Government paid 100.000 dollars to the United States Legation in June 1901.42

The same scenario was repeated in 1904. When the Ottoman authorities closed some American schools and arrested some Armenians who were naturalized United States citizens, President Roosevelt sent a powerful fleet to İzmir harbor and the United States minister Leishman, in his audience with the Sultan, mentioned the possibility of a bombardment of İzmir. As a result, Armeno-Americans were released and the schools were permitted to re-open.

However, they did not enjoy normalized conditions until Sultan Abdülhamid was overthrown from the power and a

${ }^{39}$ Foreign Relations of the United States, Washington D.C., US Government Printing Office, 1895, p. 1256.

40Ibid., pp. 1256-1265.

${ }^{41}$ Congressional Record (Senate), Washington D.C., US Government Printing Office, Vol. 28, No. 54-1, 1895-996, pp. 959-996.

${ }^{42}$ NARA, M-46, June 12, 1901; BOA, ISKD (Irade-i Seniyye Kayıt Defteri), 30 N. 1317, No: 1269. 
constitutional government was formed in 1909. The details of this period will be taken up in the concluding part.

\section{Publishing Activities of the Missionaries}

Another dimension of the missionary work in the Ottoman Empire was publication and distribution of religious and educational books and pamphlets. Printing house in Malta that was established by Pliny Fisk in 1822, published 350.000 copies of different books in Greek, Italian and Armeno-Turkish within just nine years. The printing house was moved to İzmir in 1833 and to the mission center, İstanbul, in 1852. After serving in Pera for 20 years, the printing house that was named as the "Bible House", was moved once more to Rlza Pasha Yokuşu, a region very close to the Sublime Porte. ${ }^{43}$

From its establishment to 1860 , the number of pages of the books published and distributed by the missionaries were more than 191 million. While the majority of the books were on religious subjects, some popular magazines and scientific books were also published. For instance, Avedaper, a politico-cultural magazine in Armeno-Turkish was printed by the missionaries. ${ }^{44}$

Publishing activities, targeted the non-Muslim subjects of the Empire, did not disturb the Sublime Porte. However, when in 1860 s, some Muslims converted to Christianity as a result of missionary efforts, and the Bible House began to publish books in Turkish for the use of Muslims, Sublime Porte started to impose restrictions on missionary publications. On the other hand, a general concern towards all foreign publications, including the ones distributed by Russians and Greeks, calling the Orthodox population to seek independence from the Ottoman Empire, arose suspicion in the Sublime Porte in 1860s. As a result, the Porte enforced new regulations for printing activities of the Ottoman subjects and the foreigners.

\footnotetext{
${ }^{43}$ Uygur Kocabaşoğlu, Osmanlı Imparatorluğunda XIX. Yüzyılda Amerikan Yüksek Okulları, Ankara, Mülkiyeliler Birliği Vakfı, 1988, pp. 270-271. ${ }^{44}$ Daniel, American Philantrophy, p. 102.
} 
Ali Pasha, Minister of Foreign Affairs, sent a circular to all embassies and legations in İstanbul on 27 November 1862, stating that the Sublime Porte will censor all books with contents of political or religious propaganda. ${ }^{45}$ The effects of this new regulation were seen in a short time. Beginning with the first months of 1863, the Ottoman authorities started to collect books published by foreigners, including a vast number of missionary publication that created a discontent among the Americans. The scope of this uncomfort increased when officials from the Ottoman police department (Zaptiye Nezareti) sealed a book shop owned by missionaries and confiscated some books in July 1864. When the American Minister Resident, Morris, applied to the Sublime Porte for return of the books, Ali Pasha replied that the missionaries largely distributed material among the Muslims containing false knowledge about Islam, and therefore such activities will not be allowed by the government. 46

The Sublime Porte enlarged the restrictions by an Act of Publication that was entered into force at the end of 1864 . According to the new legal regulation, all published materials, either printed in the Ottoman Empire or imported from foreign countries, were subject to the prior control and permission of the Sublime Porte for their distribution. ${ }^{47}$ Morris who visited Ali Pasha several times on behalf of the American missionaries, was told that the Sublime Porte was not against any religious material such as the Bible that was freely published and distributed, however any material that included Christianity propaganda towards the Muslims would not be tolerated. 48

The restrictions on the publications were eased in the first half of the 1870, parallel to the intensive efforts of the American, British, French and Russian diplomatic missions. But, when the Bulgarian revolt erupted during spring 1875, more restrictions were enforced. According to a new regulation, all publications were subjected to the approval of the Ministry of Public Instruction before printing. Moreover, a sentence of identification was to be placed in the front page of the publication, indicating its character,

45NARA, M-46, November 27; December 11, 1862.

46NARA, M-46, July 23, 1864.

47 NARA, M-46, January 15, 1865.

${ }^{48}$ NARA, M-46, October 18, 1865; May 17, 1866. 
such as scientific, religious, literary etc. The major objection against those new rules came from the missionaries who asked the Sublime Porte to make an exception for the publications that were ordered before the regulation, and were replied negatively. 49

Despite the strict limitations, the missionaries continued their publication activities with or without permission of the Porte. This attitude increased the disputes. In 1880s, Ottoman authorities began to confiscate missionary books at the customs. Although some publications, containing solely religious subjects, were returned to the owners due to the American Legation's initiatives, some of them with a political content were kept and even destroyed by the Porte. ${ }^{50}$ For instance in 1880 , an American missionary from the Church of Missionary Society, without permission of the Sublime Porte, imported some religious books to İstanbul and hired an Ottoman Subject, Hoca Ahmet Efendi, to translate the publications into Turkish. When the Porte learned the issue, the books were confiscated by the police and the translator was sentenced to fifteen years in prison..$^{51}$

One of the interesting examples of the Ottoman attitude towards missionary publication took place in 1883. Lewis Wallace, the United States Minister Resident in Ístanbul, applied to the Ministry of Public Instruction to obtain a permit for republishing of the Bible, which was out of print in the Ottoman Empire. ${ }^{52}$ Getting no answer from the department, Wallace this time applied to the Sublime Porte with a note verbal. The Porte, in its reply to Wallace, stated that the Ottoman Government will allow republishing of the Bible only if a sentence, "Solely for the use of Protestants" was printed in the first page of the book. Wallace, asserting that such a statement could not be found in any of the copies of Bible, which was translated into 250 languages, rejected the Sublime Porte's condition. ${ }^{53}$ Therefore the publication of the Bible was stopped in the Ottoman Empire.

${ }^{49}$ NARA, M-46, June 30, 1875.

50NARA, M-46, April 29, 1881; December 18, 1881; April 25, 1882.

51 NARA, M-46, January 4, 1880.

52NARA, M-46, May 15, 1883.

${ }^{53}$ NARA, M-46, June 13, 1883. 
The American missionaries sometimes applied to the Ottoman Government to seek redress for their confiscated books. But the Sublime Porte mostly did not make any payments and took an attitude of negligence against such applications. Like other activities of the missionaries, the publishing efforts continued to be a source of dispute at the end of the nineteenth and in the first years of the twentieth centuries.

\section{Conclusion}

After the foundation of a constitutional government in 1908, the Ottoman attitude towards the American missionaries changed in a positive way. John G. Leishman, the United States ambassador in İstanbul, wrote in his report to the Department of State that the constitutional government would not only contribute to the development of the Ottoman society, but also ease the pressures over the American citizens, including the missionaries. ${ }^{54}$ Early statements on the rights of education and publication, from the members of the new government were satisfactory for the missionaries. In late September 1908, the restrictions on printing and distribution of books and limitations for travels of the missionaries were abolished. 55

The new rule in the Empire was welcomed in the United States Congress, too, and both the Senate and the House of Representatives passed resolutions, in which they congratulated and wished good luck to the new Ottoman government. ${ }^{56}$

Changing atmosphere also gave a new impetus to the missionary activities mostly in the Eastern provinces of the Empire. Old schools were renovated and new ones were opened. The number of the American schools in the Empire reached 209 in 1913 , and the number of pupils enrolling in those schools reached 25.922 .57

${ }^{54}$ NARA, M-46, August 20; September 28, 1908.

55 NARA, M-46, September 28, 1908; Foreign Relations of the United States, 1908, pp. 755-756.

${ }^{56}$ Foreign Relations of the United States, 1908, pp. 753-754.

${ }^{57}$ Daniel, American Philantrophy, p. 94. 
However, as the Great War started in 1914, the Ottoman official attitude towards all foreigners once more changed. At the beginning, the American missionaries, as citizens of a neutral power enjoyed some privileges in comparison to British and French. But, after 1917, parallel to the United States' accession to the War, they were also subjected to heavy restrictions.

The long adventure of the American missionaries in the Ottoman Empire ended in 1918 with the de facto collapse of the Empire. After 4 years of chaos in Anatolia, Mustafa Kemal founded the Turkish Republic in 1923. This was the opening of a new period of missionary activities in the region, and the circumstances were not easier than before. 